Journal of Dairy Research (2002) $69533-540$. (C) Proprietors of Journal of Dairy Research 2002

\title{
Effects of stage of lactation and time of year on plasmin-derived proteolytic activity in bovine milk in New Zealand
}

\author{
By GINA D. NICHOLAS ${ }^{1,2}$, MARTIN J. AULDIST ${ }^{3, * \dagger, ~ P E T E R ~ C . ~ M O L A N ~}{ }^{2}$, \\ KERST STELWAGEN ${ }^{1}$ AND COLIN G. PROSSER ${ }^{1}$ \\ ${ }^{1}$ Dairy Biotechnology, AgResearch Ruakura, Private Bag 3123, Hamilton, \\ New Zealand \\ ${ }^{2}$ Department of Biological Sciences, School of Science and Technology, University of \\ Waikato, Hamilton, New Zealand \\ ${ }^{3}$ Dexcel Ltd, Private Bag 3221, Hamilton, New Zealand
}

(Received 22 August 2001 and accepted for publication 20 March 2002)

\begin{abstract}
Summary. The objective of this study was to determine the effects of stage of lactation (SOL) and time of year on plasmin-derived proteolytic activity in the milk of pasture-fed dairy cows in New Zealand. Four herds of 20 Friesian cows were used, one herd calving in each of January, April, July and October. Cows grazed ryegrass/white clover pasture only, except during June (winter) when all cows received supplementary pasture silage. Milk samples were collected on four occasions during the year (spring, summer, autumn and winter) from each cow in milk, to give a total of three samples per cow (early, mid and late lactation; $c$. 30, 120 and 220 days after calving, respectively). Milk samples were analysed for plasmin-derived proteolytic activity. There was no effect of either SOL or time of year on plasmin activity and therefore yields of plasmin followed patterns in milk yield (highest in early lactation and in summer). There were effects of both SOL and time of year on plasminogen-derived and total plasmin plus plasminogen-derived activity, both of which were highest in late lactation and in spring. Changes in plasminogen-derived activity and total plasmin plus plasminogen-derived activity due to SOL were not only due to the decrease in milk yield associated with advancing lactation, because enzyme yields were also increased with advancing lactation. Similarly, effects of time of year on plasminogen-derived activity and total plasmin plus plasminogen-derived activity could not be attributed solely to concomitant changes in milk yield, and may be influenced by the variation in the quality and quantity of feed during the year inherent in a pasture-based dairy system. Effects of SOL on proteolytic activity were greater than, and independent of, effects of time of year.
\end{abstract}

KeYwords: Milk protein, plasmin, proteolysis, lactation, seasonality.

The New Zealand dairy industry is based around the use of pasture as a low-cost feed source, which has led to widespread adoption of seasonal calving in order to

\footnotetext{
* Present address: Department of Natural Resources and Environment, Agriculture Victoria, Ellinbank VIC 3281, Australia.

$\dagger$ For correspondence; e-mail : Martin.Auldist@nre.vic.gov.au
} 
maximize pasture utilization. Most cows calve just before spring, and thus nearly all cows are at a similar stage of lactation (SOL) at any time during the year. This practice has created irregularities in the supply of milk to processors in terms of both quantity and composition, and is accompanied by seasonal variations in the manufacturing properties of the milk.

While a number of changes in milk occur during late lactation, the deterioration in cheesemaking properties is often attributed to increased activity of the bloodderived serine proteinase plasmin (EC 3.4.21.7) at that time (reviewed by Fox, 1992; Lucey, 1996). Such an increase can occur through an increased presence in milk of plasmin from the blood, or from the increased activation of the inactive zymogen plasminogen (Korycka-Dahl et al. 1983; Politis, 1996). Plasmin hydrolyzes $\beta$-casein, generating several $\gamma$-caseins and proteose peptones (Fox, 1992), while $\alpha_{\mathrm{s} 1}$-casein (Eigel, 1977; Andrews \& Alichanidis, 1983) and $\alpha_{\mathrm{s} 2}$-casein (Le Bars \& Gripon, 1989; Visser et al. 1989) are also susceptible to degradation. In turn, casein proteolysis has a detrimental effect on the coagulation properties of milk (Grufferty \& Fox, 1988).

The precise cause of changes in plasmin-derived proteolytic activity in milk throughout the year is difficult to determine in a pasture-based, seasonally calving dairying system. The levels of milk plasmin and plasminogen increase with advancing lactation (Donnelly \& Barry, 1983; Schaar, 1985; Politis \& Ng Kwai Hang, 1988; Politis et al. 1989a). In New Zealand, however, the effects of SOL are confounded by the concomitant changes in the nutritional status of cows that results from variations in the availability and quality of pasture as the dairying season progresses. Environmental changes in temperature and day length may also impact on milk composition and the plasmin-plasminogen system. This study was designed to quantify the respective effects of SOL and time of year, and their potential interaction, on proteolytic activity in milk.

MATERIALS AND METHODS

Cows and design

Details of animal management, cow age, genetic merit, live weight, condition score, estimated dry matter intake, and composition of pasture and silage offered to cows at time of sampling were reported by Auldist et al. (1998). Briefly, 80 mixed-age Friesian cows were divided into four herds of approximately 20 cows each. Insemination of each herd was staggered so that calving occurred at intervals of 3 months. Thus, one herd calved during each of January, April, July and October. This meant that during any season there were three herds in milk, each at a different SOL (and one herd dry), grazing similar pasture and exposed to similar management practices and environmental factors.

Cows were managed as separate herds on the same farm and milked twice daily through a common dairy. Each herd was offered a daily allowance of ryegrass/white clover pasture sufficient to meet metabolizable energy requirements deemed appropriate for the level of production, based on the UK dairy cow feeding standards (Agricultural Research Council, 1984). In winter (June sampling) when insufficient pasture was available to meet requirements, each herd received approximately $20 \%$ of their dry matter intake as silage. On four occasions during the year (September: spring; December: summer; March : autumn; June: winter) milk yield was recorded and a milk sample collected from each cow at morning milking. Each cow was therefore sampled during early lactation (approximately $30 \mathrm{~d}$ in milk), mid lactation (approximately $120 \mathrm{~d}$ in milk) and late lactation (approximately $220 \mathrm{~d}$ in milk). 


\section{Milk analyses}

Immediately following milking, an aliquot of fresh milk was centrifuged at $490 \mathrm{~g}$ at room temperature $\left(25^{\circ} \mathrm{C}\right)$ for $15 \mathrm{~min}$ and the fat fraction discarded. A portion $(2-5 \mathrm{ml})$ of the skim milk was incubated with $50 \mathrm{~mm} 6$-amino-n-hexanoic acid (Sigma Chemical Co., St. Louis, MO, USA) for $2 \mathrm{~h}$ at room temperature to dissociate plasmin and plasminogen from casein micelles (Politis et al. 1993). Treated skim milk was then centrifuged at $100000 \mathrm{~g}$ at $4^{\circ} \mathrm{C}$ for $1 \mathrm{~h}$ and the supernatant (milk serum fraction) was stored at $-20{ }^{\circ} \mathrm{C}$ until analysis for plasmin and plasminogen-derived activity using a modification of the method of Richardson \& Pearce (1981).

To measure total enzyme (plasmin plus plasminogen-derived) activity, $30 \mu \mathrm{l} \mathrm{milk}$ serum, $25 \mu \mathrm{l} 0 \cdot 26$ Sigma units/ml human urine urokinase (EC 3.4.21.73; Sigma) and 50 mm-Tris buffer ( $\mathrm{pH} 7.5$ to a total volume of $160 \mu \mathrm{l}$ ) was placed into each well of a 96 -well microtitre plate. The microplate was incubated at $37^{\circ} \mathrm{C}$ for $1 \mathrm{~h}$ to allow activation of plasminogen to plasmin. Then, after equilibration to $20^{\circ} \mathrm{C}, 40 \mu \mathrm{l}$ 1 mu-coumarin peptide (N-succinyl-Ala-Phe-Lys 7-amido-4-methylcoumarin; Sigma) was added and the fluorescence was measured every $30 \mathrm{~s}$ for $20 \mathrm{~min}$ at $20^{\circ} \mathrm{C}$ using a Bio-Tek FL500 fluorescence microplate reader (Bio-Tek Instruments Inc., Winooski, VT, USA). The excitation and emission wavelengths were $360 \pm 40$ and $460 \pm 40 \mathrm{~nm}$, respectively.

Plasmin activity was measured without the addition of urokinase ( $25 \mu$ l water was added in its place). Plasminogen-derived activity was calculated by difference. Under the conditions described above, a change in fluorescence intensity of 375 in $1 \mathrm{~min}$ in the reaction mixture was defined as one unit of activity. Enzyme activities are reported as units $/ \mathrm{ml}$ and yields (yield $=$ activity $\times$ milk yield).

Somatic cell count (SCC) was measured using an automated cell counter (Fossomatic 215, Foss Electric, Hillerød, Denmark; Auldist et al. 1998).

\section{Statistical analyses}

Time of year, SOL and their interaction were analysed using the restricted maximum likelihood method of the mixed model procedure in SAS (1997). Cow was specified as a random effect and SOL and time of year were specified as fixed effects. Graphs of residuals versus fitted showed variation increasing with plasmin activity and yield and thus square root transformations were applied to these results before analysis.

On any sampling occasion, cows with SCC $>400000$ cells $/ \mathrm{ml}$ (between 1 and 6 cows per group) were excluded from the analyses to avoid the confounding effect of $\mathrm{SCC}$ on plasmin and plasminogen-derived activity in milk.

\section{RESULTS}

As expected, milk yields were highest in summer and lowest in winter, and consistently highest during early lactation and lowest during late lactation (Table 1). There was a significant interaction between SOL and time of year, with the effects of SOL being greatest in winter.

Neither SOL nor time of year significantly affected plasmin activity and the pattern of results for yield of plasmin were similar to those for milk yield (Table 1). Thus, there was a significant effect of SOL and time of year, with plasmin yield highest for cows in early lactation during summer.

Both SOL and time of year significantly affected plasminogen-derived activity 
Table 1. Milk yields, and yields and activities of plasmin, plasminogen-derived enzyme and total plasmin plus plasminogen-derived enzyme in milk from cows in early $(E)$, mid $(M)$ and late $(L)$ lactation during spring (September), summer (December), autumn (March) and winter (June)

\begin{tabular}{|c|c|c|c|c|c|c|c|c|c|c|c|c|c|c|c|c|c|}
\hline & & & ( & lues are & means & for all $c$ & ows in & each her & rd, $n=$ & & & & & & & & \\
\hline & & & & & & & & & & & & & & & & Main effe & \\
\hline & & spring & & & summes & & & Autumn & & & Winter & & ithip & ED & & & \\
\hline & $\mathrm{E}$ & M & $\mathrm{L}$ & $\mathrm{E}$ & M & $\mathrm{L}$ & $\mathrm{E}$ & M & $\mathrm{L}$ & $\mathrm{E}$ & M & $\mathrm{L}$ & herds & herds & $\mathrm{SOL} \dagger$ & Season & action \\
\hline Milk yield & $13 \cdot 2$ & $9 \cdot 6$ & 8.9 & $14 \cdot 8$ & $11 \cdot 8$ & $8 \cdot 8$ & $13 \cdot 6$ & $9 \cdot 9$ & 8.5 & $11 \cdot 6$ & $8 \cdot 9$ & $5 \cdot 8$ & 0.5 & $0 \cdot 6$ & ** & ** & * \\
\hline Square root plasmin $\left(\times 10^{4}\right)$, units $/ \mathrm{ml}$ : & 134 & 129 & 144 & 132 & 126 & 130 & 134 & 132 & 132 & 129 & 139 & 134 & 4 & 5 & NS & NS & NS \\
\hline Plasminogen $\left(\times 10^{4}\right)$, units $/ \mathrm{ml}$ & $16 \cdot 5$ & $28 \cdot 4$ & $35 \cdot 5$ & $10 \cdot 1$ & $21 \cdot 8$ & $25 \cdot 7$ & $11 \cdot 3$ & $23 \cdot 8$ & $26 \cdot 2$ & $9 \cdot 3$ & $21 \cdot 4$ & $21 \cdot 6$ & $0 \cdot 20$ & $0 \cdot 24$ & ** & $* *$ & NS \\
\hline Total enzyme $\left(\times 10^{4}\right)$, units $/ \mathrm{ml}$ & $18 \cdot 3$ & $30 \cdot 0$ & $37 \cdot 7$ & $11 \cdot 8$ & $23 \cdot 4$ & $27 \cdot 4$ & $13 \cdot 1$ & $25 \cdot 6$ & $27 \cdot 9$ & $11 \cdot 1$ & $23 \cdot 3$ & $23 \cdot 4$ & $0 \cdot 20$ & $0 \cdot 24$ & $* *$ & $* *$ & NS \\
\hline Ratio (plasminogen:plasmin) & 10 & 18 & 18 & 6 & 14 & 16 & 7 & 14 & 16 & 5 & 12 & 13 & 1 & 2 & $* *$ & $* *$ & NS \\
\hline Square root plasmin yield (units) & 1.54 & $1 \cdot 25$ & $1 \cdot 36$ & $1 \cdot 61$ & $1 \cdot 37$ & $1 \cdot 21$ & 1.57 & $1 \cdot 31$ & $1 \cdot 21$ & $1 \cdot 38$ & $1 \cdot 31$ & $1 \cdot 01$ & $0 \cdot 05$ & 0.08 & $* *$ & $* *$ & $* *$ \\
\hline Plasminogen yield (units) & 22 & 28 & 31 & 15 & 26 & 24 & 15 & 24 & 22 & 11 & 19 & 12 & 2 & 3 & $* *$ & $* *$ & NS \\
\hline Total enzyme yield (units) & 24 & 30 & 33 & 18 & 28 & 25 & 17 & 25 & 24 & 13 & 20 & 14 & 2 & 3 & ** & $* *$ & NS \\
\hline
\end{tabular}

$* P<0 \cdot 05, * * P<0 \cdot 01$, NS not significant.

$\dagger$ SOL, stage of lactation.

\$ A change in fluorescence intensity in the reaction mixture of 375 in $1 \mathrm{~min}$ at $20^{\circ} \mathrm{C}$ was defined as one unit of activity. 

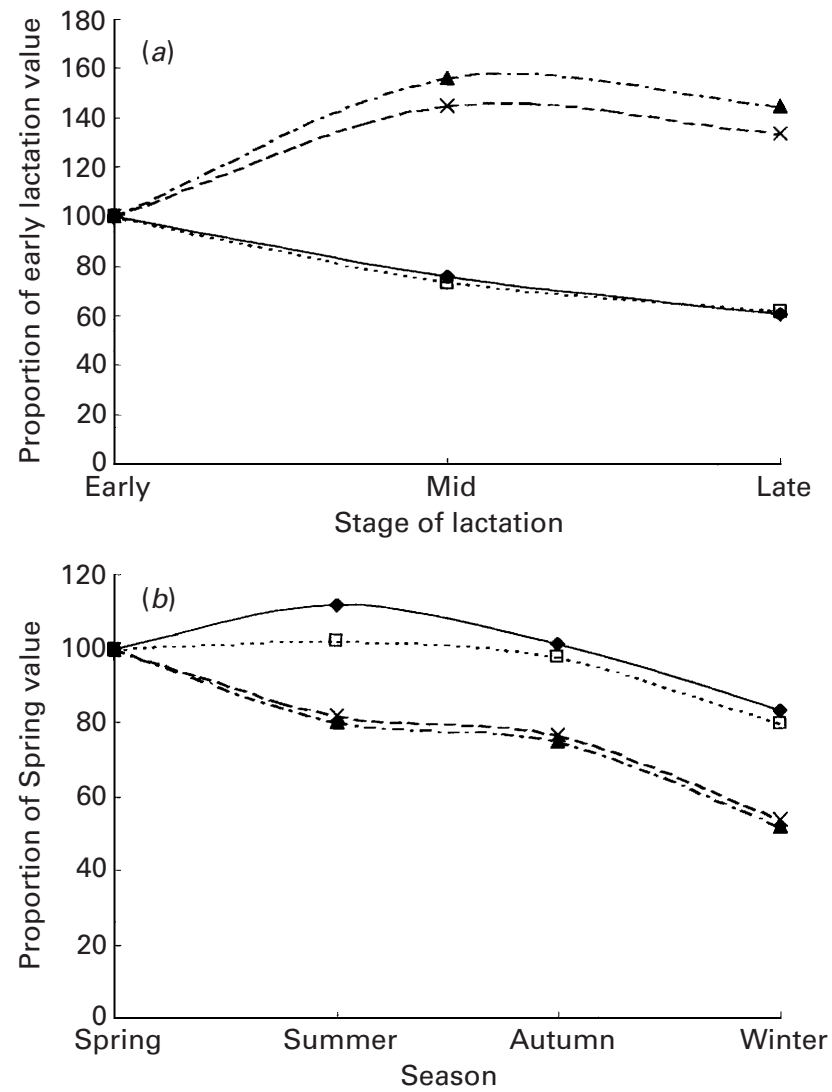

Fig. 1. Relative changes in plasmin, plasminogen, plasmin plus plasminogen-derived enzyme and milk yields due to stage of lactation and seasonal effects. (a) Values represent the average of 80 cows at each stage of lactation from all four seasons, expressed as a percentage of early lactation. (b) Values represent the average of 60 cows in each season, from all stages of lactation, expressed as a percentage of spring values. For plasmin yield, square root means were back transformed then proportions calculated. Milk yield $\left(-\bullet^{-}\right)$; plasmin yield $(\cdots \square \cdots)$; plasminogen yield $(\cdot \boldsymbol{-} \cdot \mathbf{\Delta} \cdot \mathbf{-} \cdot)$; total enzyme yield (---X--).

but there was no interaction (Table 1). Mean plasminogen-derived activity increased with advancing lactation, more than doubling from early to late lactation. Highest plasminogen-derived activities were found in spring and lowest in winter. In contrast to milk yield, which was highest in summer and early lactation, yield of plasminogen followed the overall pattern (averaged across all cows) spring $>$ summer $>$ autumn $>$ winter and early $<$ mid $>$ late lactation (Table 1). Activity and yield of total enzyme were significantly influenced by SOL and time of year, and followed the same pattern as plasminogen.

There were effects of both SOL and time of year on the ratio of plasminogen to plasmin, although there was no interaction between these effects (Table 1). The ratio increased with advancing lactation, more than doubling between early and mid lactation.

The relationship between milk yield and the yields of plasmin, plasminogen and total plasmin plus plasminogen during each SOL and at each time of year are shown in Fig. 1. Milk yield decreased with advancing lactation, by $24 \%$ from early to mid lactation, and by a further $20 \%$ from mid to late lactation. Yield of plasmin essentially mirrored this decline with advancing lactation. In contrast, there was a 
marked increase $(45 \%)$ in plasminogen and total enzyme yields from early to mid lactation then a decrease $(8 \%)$ from mid to late lactation.

The pattern in rise and fall of plasmin yield across seasons was essentially the same as that of milk yield: both increased from spring to peak in summer and then declined in autumn and further in winter. Yields of plasminogen and total enzyme differed from this general pattern by decreasing steadily from spring to winter.

\section{DISCUSSION}

Increases in plasminogen-derived enzyme activity associated with advancing lactation observed in the current study agree with previous reports (Politis et al. $1989 a$; Bastian et al. 1991). Reports of the response of plasmin activity to SOL, however, are inconsistent. In the current study there was no effect of SOL on plasmin activity. In contrast, previous reports have shown variously a gradual increase in plasmin activity with advancing lactation (Schaar, 1985), a peak at 5 months lactation (Baldi et al. 1996), a dramatic peak during late lactation (Davies \& Law, 1977; Donnelly \& Barry, 1983; Politis et al. 1989a) and differing results depending upon parity (Bastian et al. 1991).

The varying response of plasmin activity to SOL may simply represent inherent variation in cows, since wide ranges of plasmin activities have been reported within a SOL (Richardson, 1983b). Management practices such as level of feeding and milking frequency (Lacy-Hulbert et al. 1999), and cow factors such as mastitis (Auldist \& Hubble, 1998), are known to contribute to this variation. Alternatively, the variable SOL effects reported could be due to differences in the onset of involution (Politis et al. $1989 a$ ).

Increases in plasminogen-derived and total plasmin plus plasminogen-derived activities observed in this study were not only due to the concentrating effects of decreased milk yield with advancing lactation, because there were considerable increases in yields of plasminogen and total enzyme from early lactation. These findings are consistent with a substantial increase in the rate of transport of total enzyme into the gland from early to mid lactation, and then a small decrease from mid to late lactation. This contrasts with another blood protein, serum albumin, also measured in these cows, for which the increase in concentration in milk with advancing lactation was due largely to the concomitant decrease in milk yield (Auldist et al. 1998).

Owing to the increase in plasminogen-derived activity with advancing lactation, coupled with relatively constant levels of plasmin, the ratio of plasminogen : plasmin increased during mid and late lactation. This ratio can be used to represent the degree of activation of the enzyme, or the relative rates of transport into milk (Politis et al. 1989 a). These results therefore are consistent with less activation of the enzyme during mid and late lactation than early lactation. This is contrary to observations by Politis et al. (1989a) that at the end of lactation this ratio was half that in early lactation, Gilmore et al. (1995) who reported that plasminogen activator activity in the casein fraction of late lactation milk was approximately two-fold higher than in early or mid lactation, and Bastian et al. (1991) who reported that plasmin as a percentage of total plasmin plus plasminogen-derived activity increased dramatically in the last 3 months of lactation. Instead, the present study corroborates the proposition of Richardson (1983b) that increased proteinase activity occurs because more plasmin and plasminogen enter milk, rather than solely because of increased plasminogen activation. This notion is consistent with the fact that a loosening of 
mammary tight junctions, which also occurs during advancing lactation, is positively correlated with plasmin and plasminogen-derived activity in milk (Stelwagen et al. 1994).

There was a strong influence of time of year on activities and yields of plasminogen and total enzyme, with activities highest in spring followed by summer. An opposite finding was observed by Bastian et al. (1991) that activities were greatest during autumn and winter, but these authors did not include cow management details and it is difficult to rationalize these contrasting findings. Level of feeding can, however, have an influence on proteolytic activity (Nicholas, 1998), and the quantity and quality of feed in the pasture-based systems of New Zealand varies considerably, especially between seasons (Auldist et al. 1998; McCall \& Smith, 1998).

Overall, the effects of SOL on proteolytic activity in milk from grazing cows were greater than, and independent of, any influences of time of year. While the adoption of all-year-round calving may help smooth out changes in bulk milk proteolysis due to SOL, the effects of SOL and time of year appear to be additive and so seasonal calving could, for example, result in late lactation cows in spring having significantly higher levels of enzyme than they would normally have had in autumn. Thus allyear-round calving may result in an undesirable reduction in milk quality for manufacturing at certain times of the year. The effects of time of year need to be examined further, given that the present results under New Zealand conditions are the opposite of previous studies from the Northern Hemisphere, which have significantly different feeding and housing conditions. Importantly, the mechanisms driving this time of year effect, particularly the higher levels of plasmin and plasminogen-derived activity during spring, need to be examined.

We thank B. Walsh and M. Drabble for the care of cows, and R. Hooper and Dr $\mathrm{H}$. Henderson for statistical procedures. This research was funded by the Foundation for Research in Science and Technology. G. D. Nicholas was supported by an AGMARDT Doctoral Scholarship.

\section{REFERENCES}

Agricultural Research Council 1984 The nutrient requirements of ruminant livestock, Suppl. 1. Farnham Royal, England: Commonwealth Agricultural Bureaux

Andrews, A. T. \& Alichanidis, E. 1983 Proteolysis of caseins and the proteose-peptone fraction of bovine milk. Journal of Dairy Research $50275-290$

Auldist, M. J. \& Hubble, I. B. 1998 Effects of mastitis on raw milk and dairy products. Australian Journal of Dairy Technology $\mathbf{5 3} 28-36$

Auldist, M. J., Walsh, B. J. \& Thompson, N. A. 1998 Seasonal and lactational influences on milk composition in New Zealand. Journal of Dairy Research 65 401-411

Baldi, A., Savoini, G., Cheli, F., Fantuz, F., Senatore, E., Bertocchi, L. \& Politis, I. 1996 Changes in plasminplasminogen-plasminogen activator system in milk from Italian Friesian herds. International Dairy Journal $61045-1053$

Bastian, E. D., Brown, R. J. \& Ernstrom, C. A. 1991 Plasmin activity and milk coagulation. Journal of Dairy Science 74 3677-3685

Davies, D. T. \& Law, A. J. R. 1977 The composition of whole casein from the milk of Ayrshire cows. Journal of Dairy Research 44 447-454

Donnelly, W. J. \& Barry, J. G. 1983 Casein compositional studies. III. Changes in Irish milk for manufacturing and role of milk proteinase. Journal of Dairy Research 50 433-441

Eigel, W. N. 1977 Effect of bovine plasmin on $\alpha_{\mathrm{s} 1}-\mathrm{B}$ and $\kappa$-A caseins. Journal of Dairy Science $601399-1400$

Fox, P. F. 1992 Proteinases. In Advanced dairy chemistry-volume 1: proteins, pp. 310-320 (Ed. P. F. Fox). London: Elsevier Applied Science

Gilmore, J. A., White, J. H., Zavizon, B. \& Politis, I. 1995 Effects of stage of lactation and somatic cell count on plasminogen activator activity in bovine milk. Journal of Dairy Research 62 141-145

Grufferty, M. B. \& Fox, P. F. 1988 Functional properties of casein hydrolysed by alkaline milk proteinase. New Zealand Journal of Dairy Science and Technology 23 95-108 
Korycka-Dahl, M., Ribadeau Dumas, B., Chene, N., Martal, J. \& Dumas, B. R. 1983 Plasmin activity in milk. Journal of Dairy Science 66 704-711

Lacy-Hulbert, S. J., Woolford, M. W., Nicholas, G. D., Prosser, C. G. \& Stelwagen, K. 1999 Effect of milking frequency and pasture intake on milk yield and composition of late lactation cows. Journal of Dairy Science $821232-1239$

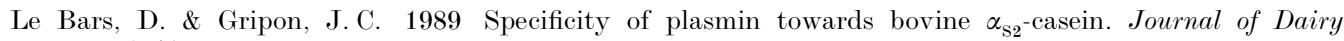
Research 56 817-821

Lucey, J. 1996 Cheesemaking from grass based seasonal milk and problems associated with late-lactation milk. Journal of the Society of Dairy Technology 49 59-64

McCall, D. G. \& Smith, J. F. 1998 Seasonal factors influencing reproductive management. In Reproductive management of grazing ruminants in New Zealand, pp. 65-76 (Eds E. D. Fielden \& J. F. Smith). Hamilton: New Zealand Society of Animal Production

Nicholas, G. D. 1998 Factors affecting plasmin and plasminogen-derived activity in bovine milk. D.Phil. Thesis, University of Waikato

Politis, I. 1996 Plasminogen activator system : implications for mammary cell growth and involution. Journal of Dairy Science 79 1097-1107

Politis, I., Lachance, E., Block, E. \& Turner, J. D. 1989 a Plasmin and plasminogen in bovine milk: a relationship with involution? Journal of Dairy Science 72 900-906

Politis, I. \& Ng Kwai Hang, K. F. 1988 Effects of somatic cell counts and milk composition on the coagulating properties of milk. Journal of Dairy Science 71 1740-1746

Politis, I., Ng Kwai Hang, K. F. \& Giroux, R. N. $1989 b$ Environmental factors affecting plasmin activity in milk. Journal of Dairy Science 72 1713-1718

Politis, I., Zavizon, B., Barbano, D. M. \& Gorewit, R. C. 1993 Enzymatic assay for the combined determination of plasmin plus plasminogen in milk : revisited. Journal of Dairy Science 76 1260-1267

Richardson, B. C. $1983 a$ The proteinases of bovine milk and the effect of pasteurisation on their activity. New Zealand Journal of Dairy Science and Technology 18 233-245

Richardson, B. C. $1983 b$ Variation of the concentration of plasmin and plasminogen in bovine milk with lactation. New Zealand Journal of Dairy Science and Technology 18 247-252

Richardson, B. C. \& Pearce, K. N. 1981 The determination of plasmin in dairy products. New Zealand Journal of Dairy Science and Technology 16 209-220

SAS 1997 SAS/STAT Software: changes and enhancements through release 6.12. Cary, NC: SAS Institute

Schaar, J. 1985 Plasmin activity and proteose-peptone content of individual milks. Journal of Dairy Research $52369-378$

Stelwagen, K., Politis, I., White, J. H., Zavizon, B., Prosser, C. G., Davis, S. R. \& Farr, V. C. 1989 Effect of milking frequency and somatotropin on the activity of plasminogen activator, plasminogen, and plasmin in bovine milk. Journal of Dairy Science 77 3577-3583

Visser, S., Slangen, K. J., Alting, A. C. \& Vreeman, H. J. 1989 Specificity of bovine plasmin in its action on bovine $\alpha_{\mathrm{S} 2}$-casein. Milchwissenschaft 44 335-339 